\author{
겸재 정선의 진경산수화에 나타난 수변의 \\ 미지형 경관 특성과 하경양식 ${ }^{+}$ \\ 김용희 ${ }^{*}$ 강영조 ${ }^{* *}$ \\ "동아대학교 대학원 도시조경학과 박사과정 ·"동아대학교 조경학과 교수
}

\title{
A Study on the Micro-Topography Landscape Characteristics and Waterfront Landscape Style of Waterfront in Korean Jingyeong Landscape Painting
}

\author{
Kim, Yong-Hee* Kang, Young-Jo*
}

"Ph.D. Course, Dept. of Urban Planning and Landscape Architecture, Graduate School, Dong-A University

${ }^{*}$ Professor, Dept. of Landscape Architecture, Dong-A University

\begin{abstract}
This study is based on the analysis of the characteristics of waterfront scenery. Recently, waterfront development has expanded residentially, commercially and into leisure space. In the development of the waterfront, it is necessary to apply designs suitable for urban and various other waterfront areas. In this study, the natural scenery of the waterfront was researched with respect to the Korean Jingyeong landscape paintings and the main elements of the scenery were analyzed.

In this study, 105 painting of Korean Jingyeong landscapes paintings were selected for the analysis of the waterside scenery. The paintings of Jeong Seon were studied to categorize streams topographically into mountainous, upper, middle, lower, and ocean types. In addition, major micro-topography elements, which are 13 water image elements and 13 staffage elements were analyzed. The main waterfront landscape elements are divided into 13 types. The waterfalls were divided into long waterfalls, short waterfalls, cascading waterfalls, and other aspects considered were line stream, curve stream, multi-curve stream, pond, water surface, flow surface, wave surface, rock side, pile sandy side, sandy side. There are 13 kinds of staffage elements, include pine forest, pine trees, fir trees, bamboo trees, willow trees, broadleaf tree, villages, houses, gazebo, boat, bridges, and people. The waterfront landscape by a river area was explained according to each characteristic of the waterfront landscape and staffage, and their changes were analyzed in each area.

The 105 paintings were divided into 35 pieces of mountainous streams, 9 upper streams, 5 middle streams, 35 lower streams, and 21 oceans, and the change of each waterfront landscape and staffage was analyzed. Based on the topographical analysis of the waterfront landscape and staffage, the results can be summarized into 5 types of the waterfront landscape.

Based on the micro-topographical characteristics of the waterfront landscape styles are as follow. In the mountainous streams, long waterfall and deep forest type are apparent, which depicts deep mountain waterfall scenery, and a multi-stream forest is the scenery of a picnic in the mountains, which is a representative form of mountainous streams landscape. In the upper-middle stream, the water-surface and gazebo type is predominant. In the lower stream, the sandy-gazebo type
\end{abstract}

\footnotetext{
${ }^{+}$: 이 논문은 동아대학교 교내연구비 지원에 의하여 연구되었음.

Corresponding author: Young-Jo Kang, Professor, Dept. of Landscape Architecture Dong-A University, Busan 49315, Korea, Tel.: +82-51-200-7576, E-mail: yjkang@dau.ac.kr
} 
scenery is predominant and the sandy depiction is unique to lower stream landscape. Pile sandy-dock type is life scenes where human activity highlighted, is a representative form of the lower stream landscapes. The characteristic of the coastal landscape is the serpentine rock scenery on the beach and the wave-serpentine rock type that forms the main coastal landscape.

The study aims to propose significant design elements for a natural waterfront landscape planning based on the analysis of landscape in the paintings of Jeong Seon.

\section{Key Words. Waterfront Landscape, Waterfront Landscape Form Micro-Topography Elements, Water Image Elements, Staffage Elements}

\section{국문초록}

본 연구는 수변경관의 특성을 겸재 정선의 진경산수화를 바탕으로 분석한 연구이다. 최근 주거, 상업 및 여가공간의 확충을 위해 수변의 개발이 많이 이루어지고 있다. 수변 개발 시에는 도심과 다른 수변공간에 적합한 디자인의 적용이 필요하다. 본 연구에서는 수변공간의 자연스러운 풍경상을 진경산수화에서 찾고, 그 풍경을 구성하는 주요 경관요소들을 분석하였다.

연구를 위해 수변 경관의 분석이 가능한 겸재 정선의 진경산수화 105 엽을 선정하였다. 105 엽을 하천지형학적 분류에 따라 산간계류, 상류, 중류, 하류, 해(海)로 분류하였고, 수변경관을 구성하는 주요 미지형 요소인 수형상 13가지, 점경요소 13 가지의 특성을 분석하였다. 주요 미지형요소 수형상은 선형, 면형, 변형으로 구분되며, 장폭, 단폭, 다단폭, 선류, 곡류, 다곡류, 담, 수면, 유수면, 탄파면, 기암변, 토파변, 토사변 등 13 가지이다. 점경요소는 자연 · 인문 요소로 구분되며, 송림, 소나무, 전나무, 대나무, 버들, 잡수, 기암, 마을, 집, 누정, 배, 다리, 사람 등 13 가지이다. 하천 구역별 수변 미지형 경관의 특징을 수형상과 점경요소들로 설명하였으며, 수형상과 점경요소들의 하천 구역별 변화 양상을 분석하였다.

105 엽은 산간계류 35 엽, 상류 9엽, 중류 5엽, 하류 35 엽, 해(海) 21 엽으로 분류되었다. 하천 구역별로 수형상과 점경요소 가 표현되는 양상을 분석한 결과, 5 가지의 하경양식과 해안의 풍경 특징을 종합할 수 있었다. 겸재 정선의 진경산수화에서 수변 미지형 경관 특성을 중심으로 분석한 하경양식은 다음과 같다. 산간계류에서는 심산속 폭포 풍경을 그린 장폭심산형, 수림지내 곡류를 유람하는 풍경인 다곡수림형이 대표적인 하경양식으로 나타났다. 중상류에서는 수변을 유람하거나, 누정이 있는 풍경인 수면누정형, 하류에서는 하류 특유의 모래톱과 누정이 있는 풍경인 토사누정형과 하류에서의 인간 활동이 부각된 생활풍경인 토파나루형이 대표적인 하경양식으로 나타났다. 해안 풍경의 특징은 바닷가의 기암절경이 주 풍경을 이루는 탄파기암형으로 나타났다.

본 연구는 겸재 정선의 진경산수화를 소재로 산수화와 경관 분야에서 아직 연구되지 않은 수변공간의 구성요소들과 수변 풍경 유형을 분석하였다.

주제어: 수변경관, 수변 풍경 유형, 수변 미지형요소, 수형상, 점경요소

\section{I. 서론}

\section{1. 연구배경 및 목적}

본 연구는 수변경관의 특성을 겸재 정선의 진경산수화를 바 탕으로 분석한 연구이다. 최근 주거, 상업 및 여가공간의 확충 을 위해 수변의 개발이 많이 이루어지고 있다. 수변 개발 시에 는 도심과 달리 수변공간에 적합한 디자인의 적용이 필요하다. $\mathrm{Kang}$ (2001)의 진경산수화 분석을 통한 산지구릉 경관 유형 의 분류 및 해석에서 "산수화는 일부의 평가가 아닌, 일반인들
의 공통적인 느낌을 이 시대에 전달해주는 귀중한 자료이다"라 고 적시하였다. 이는 산수화가 일반인들에게 자연스러운 풍경 의 공통된 상(相)을 전달해 주고 있음을 시사한다. Yoon(2006) 의 연구에서는 겸재 정선의 진경산수화를 중국풍이 아닌 조선 의 진경산수화를 그려낸 한국회화사의 커다란 변혁을 가져온 작품으로 설명하였다. 또한, 겸재 정선의 회화가 중국의 화풍 을 수용하고 소화하여 우리 산천에 어울리는 정체성에 바탕을 둔 조선 고유의 화법을 구축하였음을 명시하였다. 우리나라의 대표적 산수화가인 겸재 정선은 당시 산천 풍경을 우리나라만 의 기법으로 담아내었다. 즉, 진경산수화는 실물 화폭으로 이어 
져온 우리나라 산천의 자연스러운 풍경의 표상으로 볼 수 있다. 따라서 본 연구에서는 수변공간의 자연스러운 풍경 상을 진경 산수화에서 찾고, 그 풍경을 구성하는 주요 경관요소들을 분석 하였다.

수변 경관을 구성하는 주요한 시각적 요소는 수변 지형과 주 변 요소들이다. 여기서 수변의 지형과 주변 요소들은 대규모의 지형 요소가 아닌 미세한 지형과 점적인 요소들 말한다. 토목 분야에서 하천 미지형은 하상 및 하안의 굴곡, 침식, 퇴적 등에 변화를 주어 유로 및 하천 생태에 영향을 미치는 미세한 지형 을 말한다. 즉, 토목 분야에서는 하천 미지형(微地形)을 물의 흐름에 중심을 두고 있다. 하지만 수변의 경관은 하천 지형의 물리적 요소뿐만 아니라, 지면을 피복하고 있는 수목, 바위, 구 조물, 사람과 같은 점적인 요소들을 포함한다. 따라서 수변의 경관을 다루는 본 연구에서는 수변 미지형을 수체의 물리적 요 소인 ‘수형상 $(\text { 水形像 })^{1)}$ '과 물 주변의 점적인 지표물인 '점경요 소(點景要素) $)^{2)}$ 로 나누어 분석하였다.

수변 경관에서 자주 나타난 요소는 수변 풍경을 설명하는 중 요한 요소이다. 본 연구에서는 진경산수화에 나타난 수변의 미 지형(微地形) 경관요소들을 찾아내었다. 또한, 겸재 정선의 진 경산수화에 나타난 대표적인 수변 풍경을 5 가지 하경양식(河 景樣式 $)^{3)}$ 과 해안의 풍경으로 종합하여 수변 풍경의 특징을 미 지형 요소로 설명할 수 있었다.

\section{2. 선행연구와의 차별성 및 의의}

본 연구는 현재까지도 일반인들의 마음속에 남아있는 조선 후기의 공통적인 풍경상(風景相)을 겸재 정선의 진경산수화에 서 찾고 분석하였다. 본 절에서는 산수화를 대상으로 한 연구 중 준법(捘法)에 관한 연구와 경관분석의 도구로 사용한 연구 그리고 전통공간에 대한 원형을 다룬 연구를 조사하여 본 연구 의 방향성과 가치를 제고하였다.

겸재 정선의 진경산수화를 미술학 분야에서 다룬 연구는 Yoon(2006)의 산수화의 준법연구(겸재 회화를 중심으로)가 있 다. Yoon(2006)의 연구는 작품에서 다양한 요소들을 추출하여 분석하는 방식은 본 연구와 유사하나, 요소를 표현한 준법을 설명하는 것에 그쳤다.

Park et al.(2014)의 조선시대 산수화에 그려진 자연 풍경의 유형 구분과 특성에서는 그려진 장소, 시점에 의한 분류, 주 대 상에 의한 분류, 도명(圖名)에 의한 분류 등 3 가지 관점에서 주 요한 풍경 유형을 구분하였다. 산수화에서 주목하는 빼어난 장 소와 대상이 오래전부터 이어져 온 익숙하고 공통으로 좋아하 는 풍경이며, 이와 유사한 장소들을 좋은 풍경을 지닌 공간으 로 기술하였다.

$\operatorname{Kim}(2005)$ 의 논문에서는 특정 공간에 대한 원형을 파악하 기 위한 도구로 활용하였다. 특히 진경산수화에 나타난 소나무
숲을 분석하여 산림경관을 구성할 때 응용할 수 있는 소나무 숲의 특성을 연구하였다. Kang(2001)의 진경산수화 분석을 통 한 산지, 구릉, 경관, 유형의 분류 및 해석은 도시 계획의 관점 에서 진경산수화를 활용하고, 경관관리를 위한 도구로써 진경 산수화를 분석을 하였다. 이는 실제 경관을 다루기 위해 산수 화를 활용한 연구라는 점에서 본 연구와 방향성을 같이 한다. Yoo and Sung(2009)의 진경산수화에 표현된 풍토경관에 관 한 기초연구에서는 우리의 본래적인 풍토경관을 이해하기 위 해 진경산수화에 나타난 산체의 표현, 수체의 표현, 미기후의 표현을 유형화하고 특성을 분석하였다.

선행연구를 조사한 결과, 미술학 분야의 연구에서는 미술 양 식과 준법에 관한 내용을 주로 다루었다. 반면, 본 연구는 실제 공간의 주요 요소들을 추출하여 그 특징을 분석하였다.

진경산수화를 경관분석의 도구로 사용한 연구에서 전통공 간의 원형과 산지 구릉경관, 풍토경관에 관한 연구가 있었지 만, 수변경관을 중심으로 다룬 연구는 없었다. 본 연구는 Kang (2001)의 연구와 Yoo and Sung(2009)의 연구에서 다루지 않 은 수변의 미지형과 주요 구성요소를 세분화하고, 수변풍경의 유형을 분류하여 하경양식별 특성을 분석하였다.

본 연구는 겸재 정선의 진경산수화를 소재로 산수화와 경관 분야에서 아직 연구되지 않은 수변공간의 구성요소들과 수변 풍경 유형을 분석하였다.

\section{II. 연구의 방법}

\section{1. 재료의 선정}

산수화는 당시의 산천풍경을 보여주는 사진과 같은 역할을 한다. 하지만 장면을 그대로 보여주는 사진과는 달리 산수화는 작가의 의도에 따라 경관요소들을 부각시키거나, 생략이 가능 하다. 즉, 산수화는 실제 경관에 대한 주요 지표들의 조합으로 이루어져 있다. 이러한 산수화를 주요 경관지표 중심으로 분석 하면 작가가 당시 풍경에서 중요하게 표현한 경관요소가 무엇 인지 알 수 있다.

본 연구에서는 실존했던 경관을 그린 산수화를 연구 대상으 로 삼았다. 즉, 산수화를 통해서 당시의 실존 공간에 대한 경관 분석을 하기 위함이다. 분석 결과의 신뢰성을 위해 산수화에 대한 정보가 명확한 재료를 선정하였다. 산수화에 표현된 풍경 이 현실에서 어떤 장소를 나타낸 것인지 알 수 없는 것, 또는 정보의 부족으로 실경(實景)과 상상경(想像景)의 구분이 되지 않는 경우 분석의 소재로써는 부적합하다.

조선후기 중국풍의 영향을 받은 실경산수화 이후 한국 고유 의 산천 모습을 우리만의 기법으로 담아낸 진경산수화가 겸재 정선에 의해 정립되었다. 본 연구에서는 한국의 실경을 우리만 의 독자적 기법으로 표현하고, 우리나라의 산수화를 대표하는 
겸재 정선의 진경산수화를 연구 재료로 선정하였다. 또한, 겸재 정선의 진경산수화는 조선 후기 산천풍경에 대한 공통적인 풍 경상을 현재까지도 전해 주는 자료라는 점에서 자연스러운 수 변 풍경을 연구하기에 적합한 재료이다. 특히, 본 연구는 r겸재 정선(謴齋 鄭缮)」(Choi, 1993 $)^{4}$ 의 내용을 토대로 분석하여 '실 경(實景)'의 정확성을 제고하였다.

\section{2. 재료의 수집}

겸재 정선의 진경산수화 중 명확한 정보를 가진 작품으로 분 석을 하기 위해 Choi(1993)의 r겸재 정선」에서 다루어진 345엽 에서 연구 재료를 선정하였다. Choi(1993)의 r겸재 정선」에 기 록된 345 엽 중 74 엽은 이미지가 존재하지 않아 분석의 대상에 서 제외하였다. 현존하는 도엽 271엽은 네이버 미술작품/작가 별 작품/동양작가/조선시대작가/겸재 정선 콘텐츠5)에서 수집 하여 분석을 하였다. 연구 재료의 이미지는 최상의 해상도를 지닌 파일로 수집을 하되, 이미지의 선명도에 있어 부족한 부 분은 r겸재 정선」에 기술된 풍경, 표현기법, 대상지, 점경물에 대한 설명을 참고하여 분석하였다.

수집된 271엽을 대상으로 본 연구의 분석에 사용할 도엽을 재분류하였다. 산수풍경이 아닌 초충도, 노송도 등 근접/세밀 화와 우리나라에 존재하지 않는 중국의 고사도를 재현한 도엽, 그리고 상상에 근거한 도엽을 제외하여 178 엽의 진경산수화를 선정하였다. 선정된 도엽에서 본 연구의 분석 대상인 수경요소 가 포함된 도엽만을 재분류하여 134 엽으로 선정하였다. 그중 장소 및 구도, 표현된 요소들이 거의 동일한 도엽은 하나의 도 엽으로만 분석하였고, 수공간의 표현이 있지만 표현이 미미한 도엽 29엽을 제외하여 총 105 엽을 분석 대상으로 선정하였다.

\section{3. 분석}

각 도엽에 나타난 수변 미지형 경관 특성을 분석하기 전에 지 리적 유형 분류를 선행하였다. 표현된 장소의 실제 위치는 Choi (1993)의 「겸재 정선」을 통해 확인하였다(Figure 1 참조).

진경산수화에서 수변에 표현된 주요 요소는 겸재 정선이 선호 한 경관 요소이며, 일반인이 수변 풍경을 보는 공통된 상에 영향 을 미친 중요한 요소이다. 따라서 수변 경관의 특징을 분석하기 위해 수변을 구성하고 있는 주요 시각적인 요소들을 추출하였다. 추출된 주요 요소는 수변 경관에서 물 자체의 이미지를 만드는 수형상 13 가지와 물 주변의 이미지를 구성하는 점경요소 13 가지 이다. 하천 구역별 경관특성을 살펴보기 위해서 26 가지 주요 요 소들의 하천 구역별 표현 빈도를 분석하였다. 그 결과, 수형상과 점경요소는 하천의 지리적 유형에 따라 다르게 나타났고, 지리 적 유형 별로 수변풍경의 특성을 수형상과 점경요소를 중심으로 종합하였다. 그리고 겸재 정선의 진경산수화에 나타난 하경양식
을 지리적 유형과 수형상, 점경요소로 정의하였다.

\section{III. 진경산수화의 하천지형학적 분류 및 주 요 수변 미지형 요소}

\section{1. 진경산수화의 하천지형학적 분류}

본 연구에서는 장소에 따라 다르게 표현된 수변 경관을 분석 하기 위해 하천이 가진 생물-지리학적 속성보다는 지형학적 기본 위계에 중심을 두고 분류하였다. 하천의 기본 종단(縱斷) 위계인 상, 중, 하류 3 가지 분류체계와 진경산수화에 표현된 수 공간의 특성을 고려하여 산간계류, 상류, 중류, 하류, 해(海) 5 가지 하천 구역으로 재분류하였다(Table 1 참조). 상류 중에서 도 산지 계곡에 해당하는 구역을 산간계류로 분류하였고, 하류 의 말단부인 기수역과 바다를 해(海)로 분류하였당)

Table 1. Number of paintings by river area

\begin{tabular}{c|c|c|c|c|c|c}
\hline Classify & Sum & $\begin{array}{c}\text { Mountainous } \\
\text { (MT) }\end{array}$ & $\begin{array}{c}\text { Upper } \\
\text { (UP) }\end{array}$ & $\begin{array}{c}\text { Middle } \\
\text { (MI) }\end{array}$ & $\begin{array}{c}\text { Lower } \\
\text { (LO) }\end{array}$ & $\begin{array}{c}\text { Ocean } \\
\text { (OC) }\end{array}$ \\
\hline No. & 105 & 35 & 9 & 5 & 35 & 21 \\
\hline
\end{tabular}

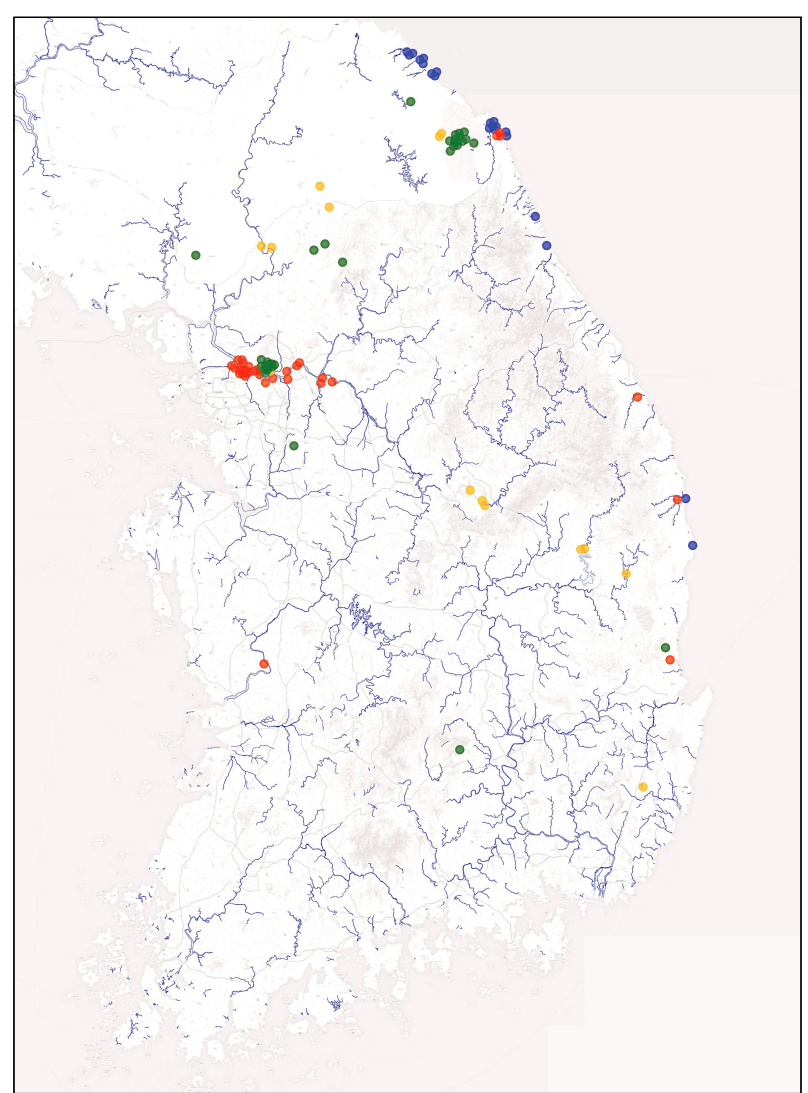

Figure 1. The actual location of the 105 analysis target painting Legend: MT UP, MI LO OC 


\section{2. 진경산수화에 나타난 주요 수변 미지형 요소}

1) 주요 수변 미지형 요소의 추출

「백천교」Figure 3에서 나타난 수형상은 짧게 떨어지는 물로 표현된 다단폭(3)을 시작으로 여러 각도로 굽이치는 다곡류로 이어져 아래로 흐른다. 우측에는 4 5미터 남짓 되어 보이는 짧은 폭포인 단폭(2)이 묘사되어 있다. 폭포 주변으로는 바위 들과 낮은 높이의 수직 암변(10)이 보인다. 점경 요소로는 자 연 요소인 전나무(C)가 화폭 전체를 둘러싸고 있으며, 계류 주 변으로 경치를 즐기는 선비들과 떠날 채비를 하는 사람들 $(\mathrm{M})$ 이 표현되어 있다. 이와 같이 각 진경산수화에 표현된 다양한 수변미지형들을 물의 형상을 보여주는 수형상과 물 주변의 점 적인 경관요소인 점경요소로 구분하여 Figure 2, 4 와 같이 추출 하였다 ${ }^{7}$.

\section{2) 수형상}

수변의 경관은 물 자체의 이미지와 물 주변의 이미지가 조합 되어 있다. 물 자체의 이미지는 떨어지고, 흐르고, 고이는 물의 움직임과 수면의 상태 그리고 물을 담고 있는 지형에 따라 다 르게 나타난다. 물 자체의 이미지인 수형상은 떨어지고 흐르는 '선'의 이미지, 수면의 질감에 따른 '면'의 이미지, 물가의 지형 에 따른 '변'의 이미지로 분류하였다.

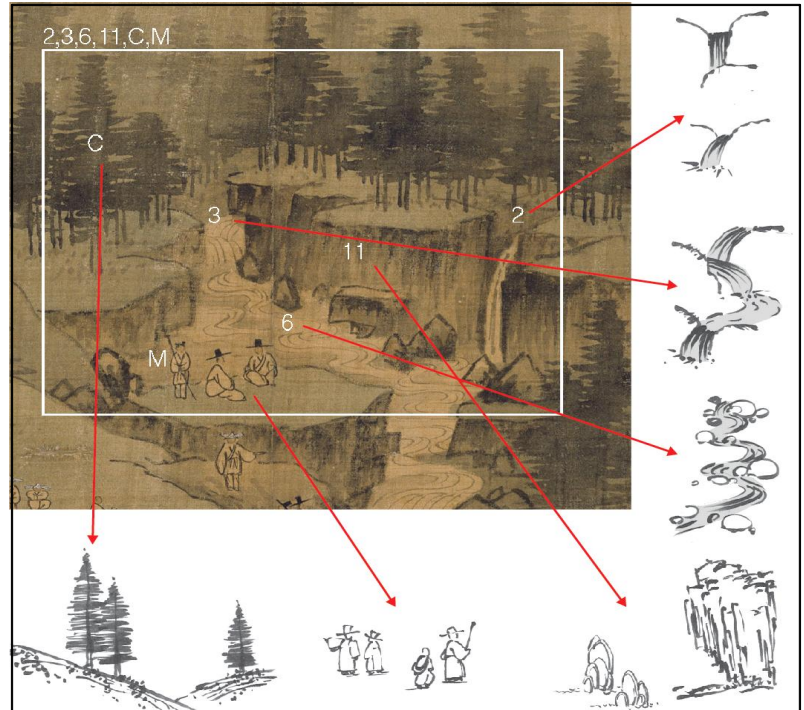

Figure 3. Water image elements and staffage elements in rBaekcheongyo」

떨어지는 '낙(落)'의 형상에서 장폭은 심산 폭포의 풍경에서 중심이 되는 요소로써 한 번에 길게 떨어지는 폭포이다. 단폭 은 도엽의 좌, 우측 한 켠에서 조용히 짧게 떨어지는 모습이다. 다단폭은 짧게 여러 번 떨어지면서 풍경의 중심에 자리하거나 가장자리에 표현되고 있다.

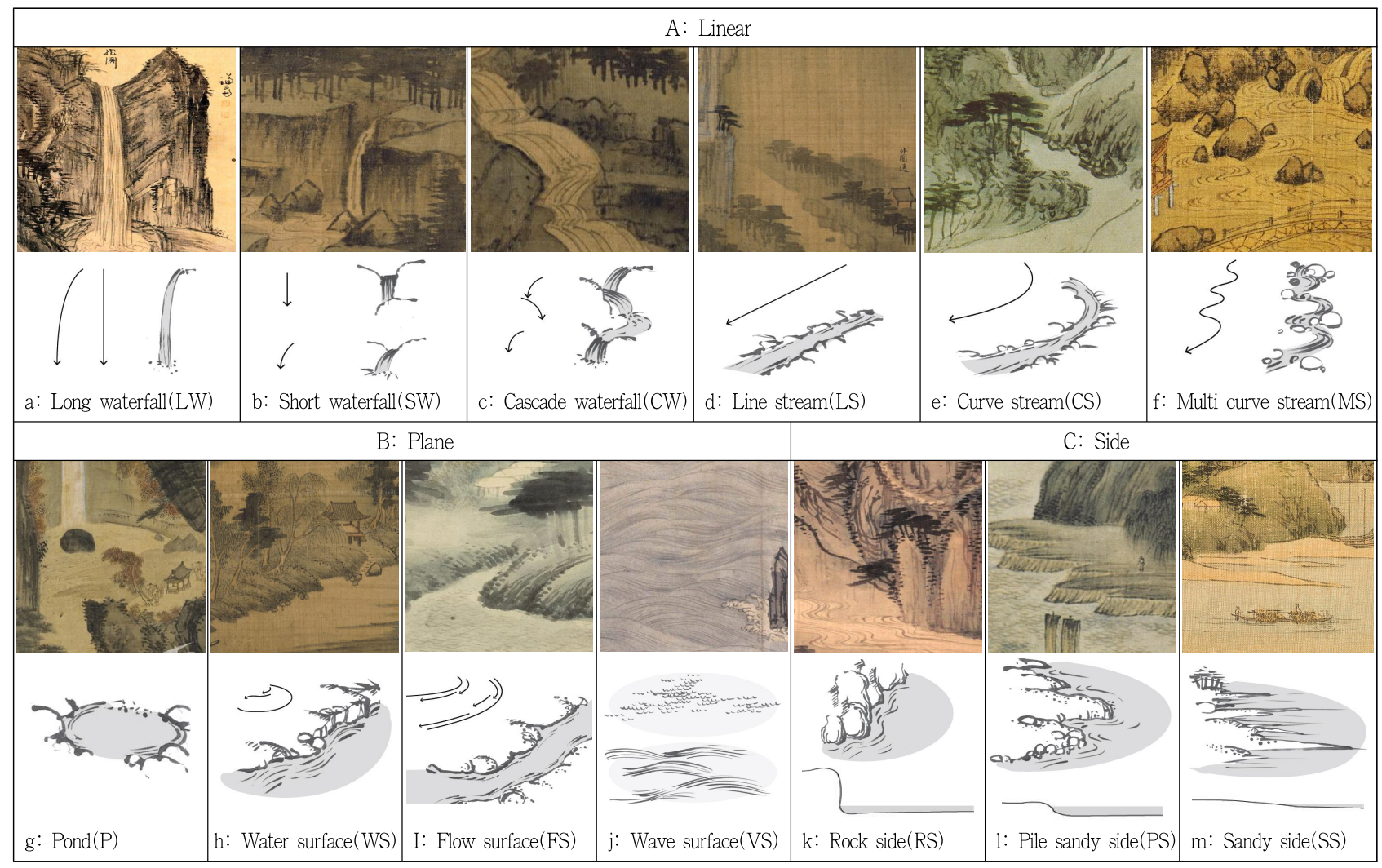

Figure 2. 13 water image elements in the Korean Jingyeong landscape painting 
떨어지고 난 뒤 흐르는 '류(流)'의 형상은 직선으로 흐르는 선류, 한번 휘어지며 흐르는 곡류, 여러 번 굽이치며 흐르는 다 곡류로 분류된다. 떨어진 뒤 잠시 머무르는 구간에서 고여있는 수형상은 '담(潭)'으로 분류하였다. 물의 수면이 화폭에서 보 다 넓게 나타나며, 느린 유속의 이미지로 표현되는 '수면'형에 서 '수면'은 정지된 느낌의 물 흐름과 함께 수변 한 쪽이 화폭 에 표현되지 않아 하폭이 넓게 느껴진다. ‘유수면’은 물 흐름이 느껴지며, 수면의 양안이 화폭에 표현되어 공간을 구분하는 역 할을 하기도 한다.

수면의 질감이 표현된 것을 '탄파면(灘波面) $)^{8}$ '으로 분류하였 다. 여울이나 바람에 일렁이는 잔물결 형태인 '탄'의 형상과 바다 에서 파도의 물결 형태인 '파'의 형상을 '탄파면'으로 분류하였다.

물의 가장자리인 '강안(江岸)'은 급격한 높이차를 보이며, 기 암들로 구성된 '기암(奇嚴)변', 평탄한 흙더미나 돌무더기로 수 면과 맞닿는 끝부분이 짧게 떨어지는 '토파(土坡)변9', 완만한 모래톱이 수면으로 길게 스며들어 여러 겹의 뾰족한 수변을 만 들어 내는 ‘토사(土沙)변’으로 분류하였다.

\section{3) 점경요소}

105 엽에서 수변에 주로 나타난 점경 요소를 자연요소와 인
문요소로 나누어 Figure 4와 같이 13가지로 분류하였다.

자연요소는 주로 나무와 바위로 나타났고, 인문요소는 사람 들의 정주 활동 및 유람에 의한 요소들이 나타났다. 자연요소 는 군락으로 표현된 송림, 단식으로 표현된 소나무, 전나무, 대 나무, 버들 그리고 정확한 수종을 알 수 없는 잡수(雜樹)와 기 암(奇㘎)으로 분류된다.

인문요소는 소규모로 촌락을 이룬 '마을', 독립된 거주형태의 '집', 명승지에 주로 자리하는 '누정'과 활발한 인간 활동을 보 여주는 배, 다리, 사람으로 분류하였다.

\section{IV. 겸재 정선의 진경산수화에 나타난 수변 의 미지형 경관 특성}

\section{1. 수형상과 점경요소 분석}

105 엽에 표현된 수형상 및 점경요소들을 분석하여 Table 2 5와 같은 방식으로 분석하여 그 결과를 개별 분석표 105 sheet를 작성하였다. 개별 분석표 105 sheet를 하나의 표로 취 합하고, 장소별로 재분류하여 하천 구역에 따라 다르게 나타나 는 경관요소의 특성을 분석했다.

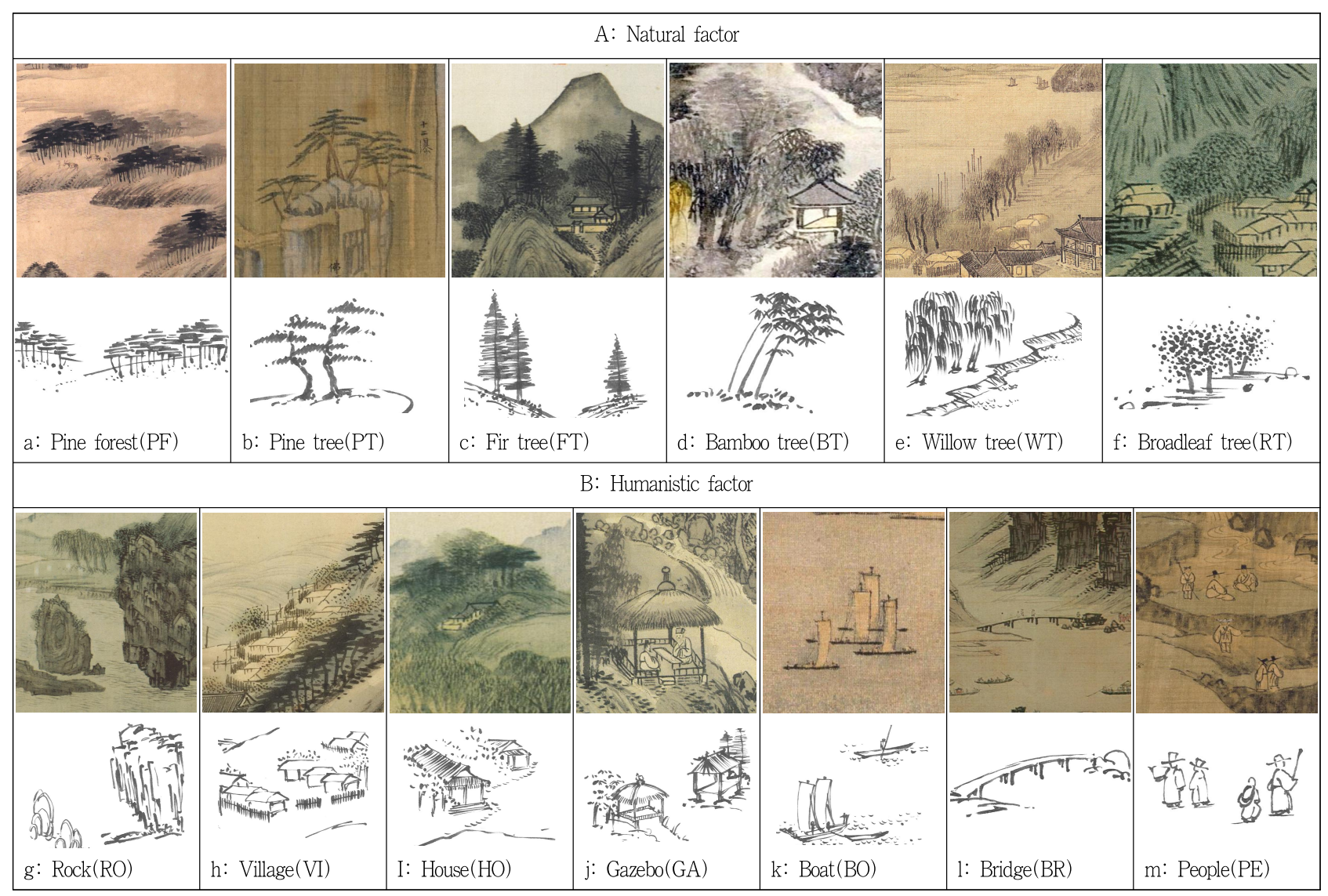

Figure 4. 13 staffage elements in the Korean Jingyeong landscape painting 
Table 2. 'Baekcheongyo」(MT) water image elements and staffage elements sheet

\begin{tabular}{|c|c|c|c|c|c|c|c|c|c|c|c|c|c|c|c|c|c|c|c|}
\hline No. & \multicolumn{2}{|c|}{ Painting name } & \multicolumn{4}{|c|}{ Riverarea } & \multicolumn{13}{|c|}{ Water image elements } \\
\hline 003 & 1711 & Baekcheongyo & MT & UP & MI & LO & \multicolumn{2}{|c|}{ Water fall } & \multicolumn{4}{|c|}{ Stream } & Pond & \multicolumn{3}{|c|}{ Plane } & \multicolumn{3}{|c|}{ Side } \\
\hline & & & & & & $y^{2}$ & $\overline{\mathrm{SW}}$ & $\mathrm{CV}$ & L & & $\mathrm{CS}$ & $\mathrm{MS}$ & $\mathrm{P}$ & WS & FS & VS & $\mathrm{RS}$ & $\overline{P S}$ & SS \\
\hline & & & & & & & 2 & 3 & & & (1) & 6 & (1) & (8) & (9) & (10) & (11) & (1) & (B) \\
\hline & & & & & & & \multicolumn{13}{|c|}{ Staffage elements } \\
\hline & & & & & & & \multicolumn{7}{|c|}{ Natural factor } & \multicolumn{6}{|c|}{ Humanistic factor } \\
\hline & & & & & & & $\overline{\mathrm{PT}}$ & $\overline{\mathrm{FT}}$ & $\bar{B}$ & & WT & RT & $\mathrm{RO}$ & $\overline{\mathrm{VI}}$ & $\mathrm{HO}$ & $\mathrm{GA}$ & $\mathrm{BO}$ & $\mathrm{BR}$ & $\mathrm{PE}$ \\
\hline & & & & & & & B & C & 0 & & (ㄱ) & (1) & (4) & (1) & (1) & (1) & (18) & (1) & (1) \\
\hline
\end{tabular}

Table 3. rUhwadeungseon,(UP, Ml) water image elements and staffage elements sheet

\begin{tabular}{|c|c|c|c|c|c|c|c|c|c|c|c|c|c|c|c|c|c|}
\hline No. & \multicolumn{2}{|c|}{ Painting name } & \multicolumn{3}{|c|}{ Riverarea } & \multicolumn{12}{|c|}{ Water image elements } \\
\hline 052 & 1742 & Uhwadeungseon & \multirow{2}{*}{\multicolumn{2}{|c|}{\begin{tabular}{|l|l|l|} 
MT & UP & MI \\
\end{tabular}}} & \multirow[t]{2}{*}{ LO } & \multicolumn{2}{|c|}{ Water fall } & \multicolumn{3}{|c|}{ Stream } & \multirow{2}{*}{\begin{tabular}{|c|} 
Pond \\
$\mathrm{P}$
\end{tabular}} & \multicolumn{3}{|c|}{ Plane } & \multicolumn{3}{|c|}{ Side } \\
\hline & & & & & & $\mathrm{SW}$ & $\mathrm{CW}$ & LS & CS & $\mathrm{MS}$ & & WS & FS & VS & $\mathrm{RS}$ & PS & SS \\
\hline & & & & & & (2) & (3) & (4) & (1) & (1) & (1) & 8 & (9) & (10) & (1) & (1) & (13) \\
\hline & & & & & & & & & & & fage el & nents & & & & & \\
\hline & & & & & & & & ural & actor & & & & & man & ic $\mathrm{fac}$ & & \\
\hline Ex & & & & 校 & & $\mathrm{PT}$ & $\overline{\mathrm{FT}}$ & $\overline{B T}$ & WT & RT & $\mathrm{RO}$ & $\mathrm{VI}$ & $\overline{\mathrm{HO}}$ & $\overline{G A}$ & $\mathrm{BO}$ & $\overline{B R}$ & $\mathrm{PE}$ \\
\hline & & Ras & & & & B & C & (1) & () & F & (c) & $\oplus$ & (1) & (1) & (B) & (1) & (11) \\
\hline
\end{tabular}

Table 4. '`Apgujeong」(LO) water image elements and staffage elements sheet

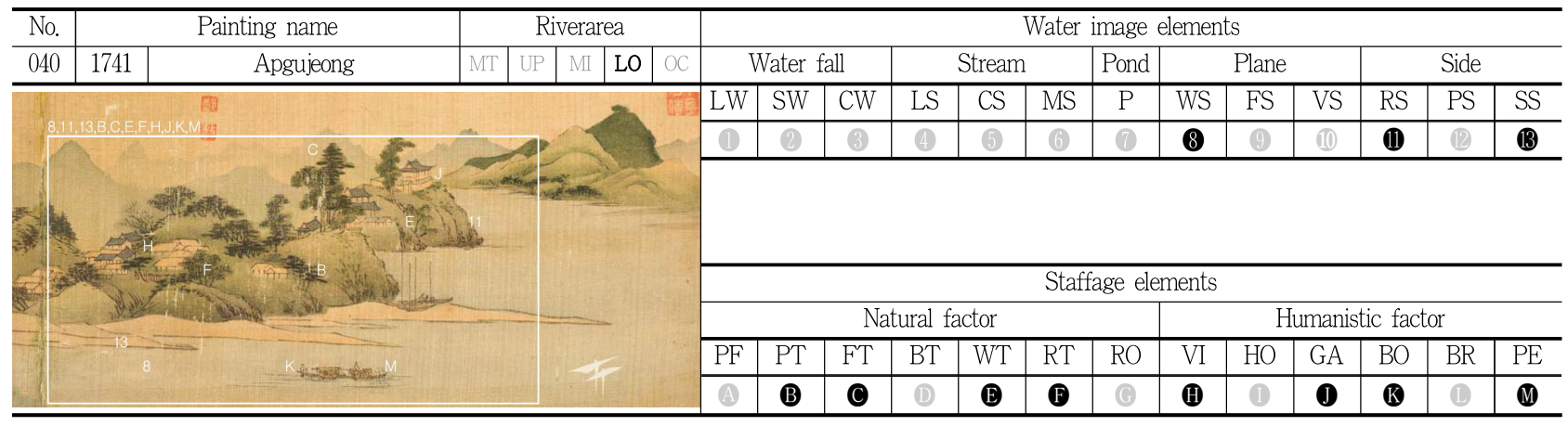

Table 5. rCheongganjeong (OC) water image elements and staffage elements sheet

\begin{tabular}{|c|c|c|c|c|c|c|c|c|c|c|c|c|c|c|c|c|c|c|}
\hline No. & \multicolumn{2}{|r|}{ Painting name } & \multicolumn{3}{|c|}{ Riverarea } & \multicolumn{13}{|c|}{ Water image elements } \\
\hline 024 & 1738 & Cheongganjeong & MT & \begin{tabular}{|l|l|} 
UP & MI \\
\end{tabular} & LO & \multicolumn{3}{|c|}{ Water fall } & \multicolumn{3}{|c|}{ Stream } & Pond & \multicolumn{3}{|c|}{ Plane } & \multicolumn{3}{|c|}{ Side } \\
\hline & & & & & & LW & SW & $\mathrm{CW}$ & LS & $\mathrm{CS}$ & MS & $\mathrm{P}$ & WS & FS & VS & RS & $\overline{P S}$ & $\mathrm{SS}$ \\
\hline & & & & & & (1) & (2) & (3) & (4) & (1) & (6) & (1) & 8 & (9) & (11) & (11) & (1) & (13) \\
\hline & & & & & & \multicolumn{13}{|c|}{ Staffage elements } \\
\hline & & & & & & \multicolumn{7}{|c|}{ Natural factor } & \multicolumn{6}{|c|}{ Humanistic factor } \\
\hline & & & & & & $\overline{\mathrm{PF}}$ & $\mathrm{PT}$ & FT & $\mathrm{BT}$ & WT & RT & $\mathrm{RO}$ & $\mathrm{VI}$ & $\mathrm{HO}$ & $\mathrm{GA}$ & $\mathrm{BO}$ & $\overline{\mathrm{BR}}$ & $\mathrm{PE}$ \\
\hline & & 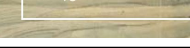 & & & & (A) & B & (C) & (1) & (i) & F & $G$ & $\mathbb{H}$ & (1) & (1) & B & (1) & (11) \\
\hline
\end{tabular}

32 한국조경학회지 제 47권 1호(2019년 2월) 
Table 6. Synthesis of water image elements and staffage elements sheet in the Korean Jingyeong landscape painting

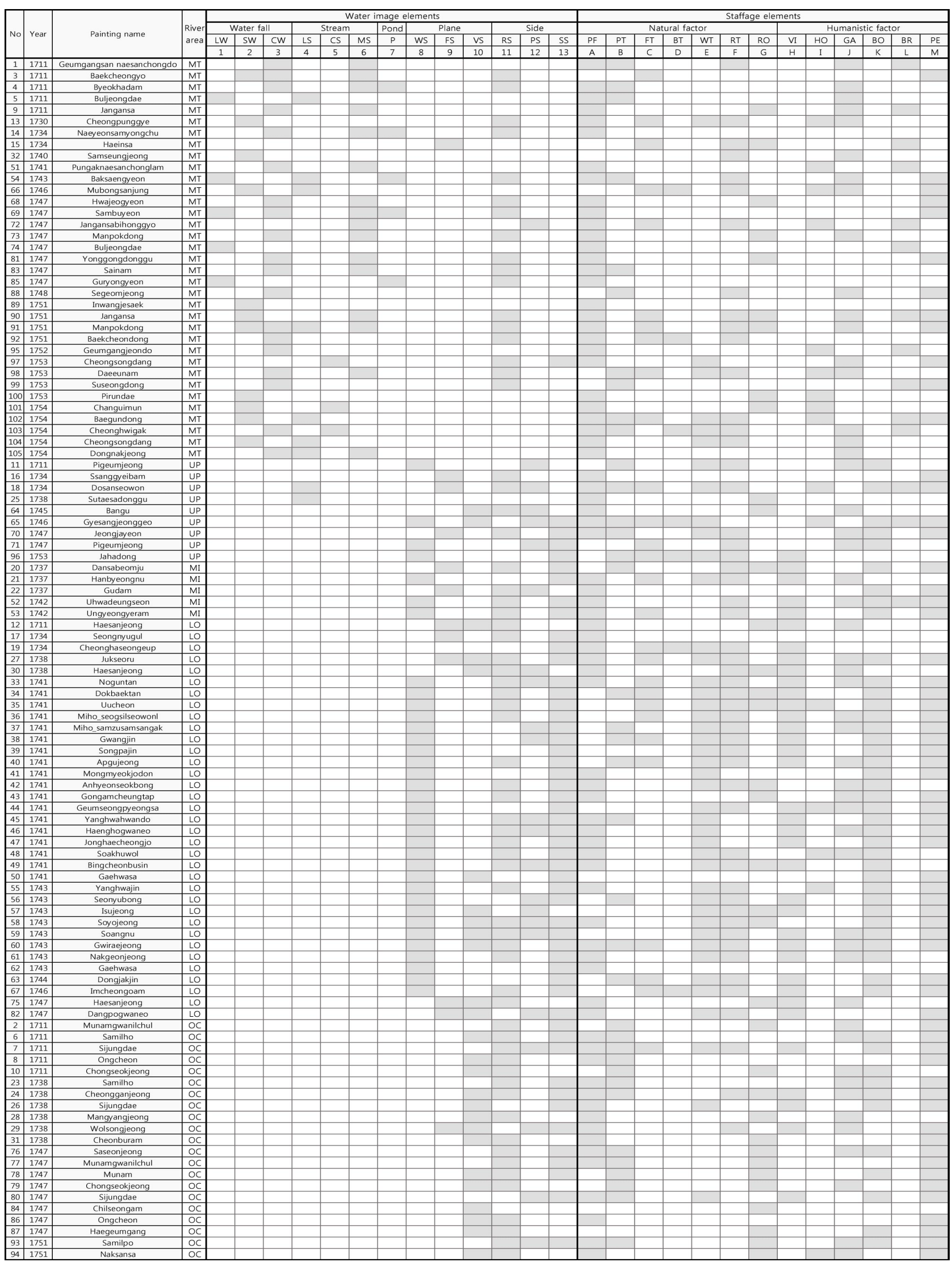




\section{2. 하천 구역별 경관 특성}

105 엽을 분석한 결과, 산간계류는 35 엽, 상류 9 엽, 중류 5 엽, 하류 35 엽, 바다(석호 ${ }^{10)}$ 포함) 21 엽으로 분류되었다. 이중 상류 와 중류의 도엽수가 상대적으로 적게 나타났다(Table 6 참조).

하천 구역별 경관 특성을 분석하기 위해 수형상과 점경요소 가 나타나는 빈도수를 Table 7,8 과 같이 정리하였다.

수형상의 표현은 산간계류, 상류, 중류, 하류, 해(海)의 5 가 지 분류에서 확연히 다르게 나타났다. 점경요소는 대체로 고르 게 표현되었으나, 전나무, 버들, 잡수, 기암, 마을, 배 등의 점경 물이 특정 구간에 집중되어 나타나는 특성을 보였다.

\section{1) 산간계류의 경관특성}

총 35 엽으로 분류된 도엽에서 수형상은 주로 선형으로 표현 된 낙수와 곡수가 고르게 나타나고, 폭포나 계곡에서 '담'의 표 현도 자주 나타났다. 주로 떨어지고, 흐르는 물 위주로 표현되 며, 수변은 산세에 기인한 기암변이 자주 표현되었다.

점경요소는 대체로 고르게 나타났으나, 표현 빈도는 나머지 구역에 비해 낮은 편이다. 송림이 거의 전체 도엽에서 나타났 으며, 소나무, 전나무, 잡수 등은 고르게 나타났고, 대나무와 버 들이 가장 적게 표현되었다. 인문요소 중 마을과 배는 표현되 지 않았으며, 산세의 절경을 감상하기 위한 정자와 사람의 표 현이 주를 이루고 있다. 계류를 건너기 위한 다리도 자주 표현

Table 7. Frequency of water image elements

\begin{tabular}{|c|c|c|c|c|c|c|c|c|c|c|c|c|c|}
\hline \multirow{4}{*}{$\begin{array}{c}\text { Clas- }^{-} \\
\text {sify } \\
\end{array}$} & \multicolumn{13}{|c|}{ Water image elements } \\
\hline & \multicolumn{6}{|c|}{ Linear } & \multicolumn{4}{|c|}{ Plane } & \multirow{2}{*}{\multicolumn{3}{|c|}{$\begin{array}{l}\text { Side } \\
\text { Side }\end{array}$}} \\
\hline & \multicolumn{3}{|c|}{ Water fall } & \multicolumn{3}{|c|}{ Stream } & \multirow{2}{*}{$\begin{array}{c}\text { Pond } \\
\mathrm{P}\end{array}$} & \multicolumn{3}{|c|}{ Plane } & & & \\
\hline & $\mathrm{LW}$ & SW & $\mathrm{CW}$ & LS & CS & MS & & WS & FS & VS & RS & PS & SS \\
\hline MT & 5 & 11 & 19 & 7 & 3 & 16 & 5 & - & 1 & - & 16 & 1 & 1 \\
\hline UP & - & - & - & 2 & - & - & - & 4 & 3 & 2 & 4 & 5 & 4 \\
\hline MI & - & - & - & - & 2 & 4 & 4 & - & - & - & - & - & - \\
\hline LO & - & - & - & - & - & - & - & 28 & 5 & 10 & 23 & 12 & 31 \\
\hline $\mathrm{OC}$ & - & - & - & - & - & - & - & - & 1 & 14 & 17 & 4 & 12 \\
\hline Sum & 5 & 11 & 19 & 9 & 5 & 20 & 9 & 32 & 10 & 26 & 60 & 22 & 48 \\
\hline
\end{tabular}

Table 8. Frequency of staffage elements

\begin{tabular}{c|c|c|c|c|c|c|c|c|c|c|c|c|c}
\hline $\begin{array}{c}\text { Clas- } \\
\text { sify }\end{array}$ & \multicolumn{10}{c}{ Staffage elements } \\
\cline { 2 - 18 } & \multicolumn{10}{c|}{ Natural factor } & \multicolumn{1}{c|}{ Humanistic factor } \\
\hline MT & PF & PT & FT & BT & WT & RT & RO & VI & HO & GA & BO & BR & PE \\
\hline UP & 28 & 10 & 10 & 3 & 6 & 15 & 9 & - & 9 & 17 & - & 11 & 12 \\
\hline MI & 6 & 5 & 4 & 2 & 5 & 5 & 2 & 1 & 2 & 4 & 5 & 2 & 4 \\
\hline LO & 4 & 1 & 2 & - & 1 & 4 & 1 & 4 & - & 2 & 4 & 1 & 4 \\
\hline OC & 21 & 8 & 11 & 2 & 28 & 25 & 9 & 26 & 4 & 16 & 28 & - & 25 \\
\hline Sum & 15 & 13 & 1 & - & 3 & 3 & 13 & 5 & 1 & 11 & 11 & - & 18 \\
\hline Total & 74 & 37 & 28 & 7 & 43 & 52 & 34 & 36 & 16 & 50 & 48 & 14 & 63 \\
\hline
\end{tabular}

되었다.

산간계류에서 나타난 수형상은 산세의 변화에 영향을 크게 받은 결과이다. 백두대간에서 동해와 서해로 이어지는 우리나 라 산세의 특성상 넓은 폭으로 떨어지는 물보다는 좁고 길게 또는 여러 단으로 떨어지는 물의 이미지가 우리 산수에 어울림 을 유추할 수 있다. 산간계류의 대표적인 풍경은 좁은 산세 사 이를 굽이치며 흐르는 다곡류와 주변에서 풍류를 즐기거나 조 망하는 선비들의 모습이다.

\section{2) 중, 상류의 경관특성}

상류와 중류는 불분명한 경계 특성상 분류된 도엽의 수가 적 으며, 나타나는 수변경관 역시 비슷한 양상을 보였다. 상류 9 엽, 중류 5 엽으로 분류된 도엽에서 수형상은 대부분 흐르는 수면 의 형태였으며, 소폭, 다단폭, 선류, 다곡류가 부분적으로 나타 났다. 특히, 물의 가장자리 표현인 강안에서 토파변과 토사변의 표현이 나타나기 시작한다. 점경요소는 모든 요소가 고르게 나 타났다. 송림과 전나무는 산간계류와 비슷하게 나타났고, 버들 의 표현 빈도가 높아졌다. 특히, 정주활동과 연관이 깊은 마을 과 배의 표현이 두드러진다.

중, 상류에서 수형상은 떨어지는 형상이 아닌 흐르는 형상으 로 바뀌었고, 산간계류보다 더 다양한 형태의 강안이 표현되 었다. 정주공간과 가까워지는 특성상 다양한 점경요소가 나타 나기 시작하며, 보다 풍성한 수변경관을 만들어낸다. 산간계류 와 달리 중, 상류에서는 산세와 물 자체의 이미지보다는 수변 의 미지형이 수변경관을 구성하는 주요 요소임을 알 수 있다. 다 만 상대적으로 적은 수의 도엽, 지리적 경계의 모호함으로 인 해 상류, 중류만의 특성이라고 하기보다는 산간계류와 하류의 경관이 전이되거나 교차되어 나타나는 풍경으로 볼 수 있다.

\section{3) 하류의 경관특성}

총 35엽으로 분류된 도엽에서 수형상은 낙수와 유수의 선형 은 나타나지 않았고, 넓은 하류의 수면의 표현이 대부분이었다. 넓은 수면의 경계를 구성하는 기암변, 토파변, 토사변이 주로 표현되며, 특히 퇴적된 모래의 형상인 토사변의 표현이 많이 나타났다. 점경요소는 송림과 전나무의 표현 빈도가 줄어들고, 잡수와 버들의 표현이 거의 모든 도엽에 나타났다. 정주공간의 특성을 반영하는 마을과 배, 사람의 표현 역시 거의 모든 도엽 에 나타났다.

하류에서는 낙수와 곡수 등의 수형상은 사라지고 유수면과 수변의 미지형에 의한 경관 위주로 표현되었다. 이는 물 자체 의 이미지나 주변의 산세가 아닌 물 주변 즉, 수변 경관이 화폭 의 중심이 됨을 보여준다. 수변의 미지형이 수변 경관의 중심 이 되는 것은 중, 상류에서도 나타났지만, 하류의 경관에서 보 다 확연하게 나타났다.

하류의 경관을 구성하는 주요 수변 요소는 버들과 잡수이다. 
이것들은 선형이나 독립된 배치가 아닌 군락의 형태로 모여 있 고, 마을의 주변 또는 배경으로 구성되어 하류의 취락지 풍경 을 만들어낸다. 취락 지역 주변에는 그곳에서 생활하거나, 드나 드는 사람들이 이동과 어업 수단인 배와 함께 강변 생활의 정 취가 묻어나는 풍경이 만들어진다. 특히 하류의 수변형태를 표 현하는 강안의 모습에서 완만한 토사변의 표현이 하류 특유의 모습을 만들어 내고 있다.

\section{4) 해(海)의 경관특성}

바다를 주 대상으로 표현한 도엽에서 특이하게 해변과 함께 동해바다에 접해 있는 석호의 경관이 많이 나타났다. 석호는 해변과 맞닿은 자연호수의 특별한 경관을 지닌 명승이다. 또한 석호는 아니지만 바다에 가까운 자연호수로 강원도 고성군에 위치한 '삼일호' 역시 동해바다의 일출과 함께 겸재 정선의 진 경산수화에 자주 나타나는 장소이다. 해변에서 만들어진 석호 는 아니지만, 먼 바다와 함께 석호의 경관과 유사하게 표현되 어 '해' 분류에 포함하여 분석하였다.

총 21 엽으로 분류된 도엽에서 수형상은 파도의 표현인 탄파 면과 토사변이 주로 나타나며, 해변 가까이에 기암들의 묘사가 특징적이다. 점경요소는 송림과 소나무의 표현은 여전히 많이 나타나지만, 나머지 수종들은 거의 나타나지 않았다. 인문요소 는 바닷가 주변의 마을과 배의 표현이 자주 나타났다.

수형상은 탄파면으로 표현된 바다의 수면이 특징적이며, 강 안은 기암변이 대부분이다. 경관의 구성은 해안에 생성된 거대 한 기암과 풍광을 조망하기 위한 정자가 조화를 이루고 있다. 버들, 잡수 등의 수목은 줄어들고, 해안 환경에 적합한 송림이 주로 표현되었다. 특히, 바다가 아닌 호수형태의 석호 지형이 주요 명승으로써 바다와 함께 표현되었다. 해(海)의 수변경관 은 우뚝 솟은 기암과 그곳에 자리 잡은 정자들이 중심을 이루 고 있다.

\section{3. 수형상과 점경요소의 양상으로 본 수변경관}

\section{1) 수형상의 변화}

수형상은 하천 구역에 따라 확연한 차이를 보였다. 산간계류 에서는 낙수와 곡수 형태의 선형이 주를 이루었고, 하류로 내려 가며 수면으로 표현된 흐르는 물과 그 주변의 강안의 표현이 다양하게 나타났다. 기암변은 구역에 관계없이 나타났다. 이것 은 절경 또는 명승을 작품의 주 대상으로 한 결과이다. 모든 구 역에서 기암변이 나타나지만, 바다 주변에서 나타나는 기암은 평탄한 주변 지형을 배경으로 묘사되어 더욱 인상적인 풍경을 만들어 내고 있다. 특히, 토사변의 표현이 하류와 바다에서 두 드러지게 나타나며, 예각의 토사 표현은 하류의 대표적인 수변 경관요소임을 알 수 있다.
2) 점경요소의 변화

점경요소 중 송림은 전 구역에 걸쳐 고르게 나타났다. 이는 우리나라 산세가 지닌 특징에서 비롯된 결과이다. 식물 요소 중 대나무가 산수화임에도 불구하고 드물게 나타났다. 이는 수 변을 중심으로 작품을 선정한 것에 기인하며, 수변 경관에 대 나무는 자주 나타나지 않았다는 것을 알 수 있다.

전나무, 버들, 잡수의 표현 빈도를 보면 산간계류와 상류에 서는 전나무가 자주 나타났지만 중, 하류에서는 버들이 자주 나타났다. 그리고 잡수는 전체 구역에서 나타났지만 하류에 더 집중된 것을 알 수 있다.

수형상과 점경요소를 하천구역별로 분석한 결과, 산간계류 와 상류에서는 수형상이 수변 경관의 중심요소이지만, 하류로 갈수록 수형상보다는 점경요소들이 주요한 수변 경관요소로 자리하고 있음을 알 수 있다.

\section{V.겸재 정선의 진경산수화에 나타난 수변 풍경의 하경양식}

지금까지 겸재 정선의 진경산수화에 나타난 수변 경관을 수 형상과 점경요소를 중심으로 분석하여 하천 구역별 경관 특성 을 정의하고, 하천 구역별로 다르게 나타나는 수형상과 점경요 소의 표현 빈도와 주요 풍경을 정리하였다. 하천 구역별로 집 중되어 나타나는 미지형 요소에 주요 풍경을 간략히 기입하였 다(Table 9 참조). 이와 같이 진경산수화에 나타난 수변 경관을 분석하여 대표적인 주요 수변 풍경을 5 가지 하경양식으로 유형 화 하였다. 또한, 하천의 풍경은 아니지만 본 연구에서 다룬 해 (海)의 구역에서 볼 수 있는 해안의 특징적인 풍경을 추가적으 로 유형화할 수 있었다(Table 10, Figure 5 참조).

산간계류에서 나타나는 장폭심산 유형은 산세와 기암에 의 해 특징지어지는 유형이다. 이 유형은 길게 떨어지는 폭포와 폭 포 하단의 담을 거쳐 다곡류로 흘러가는 수형상을 보인다. 점 경요소는 송림, 정자, 기암, 조망하는 사람으로 이루어진다. 깊 고 높은 산세를 지닌 우리나라 지형의 특징과 산수를 유람하는 선비들의 모습을 잘 나타내는 유형이다.

산간계류에서 나타나는 다곡수림 유형은 중상류로 접어들기 전 산중 계곡의 표현으로 특징지어진다. 소단폭에 의해 시작된 물이 다곡류와 소단폭을 번갈아가며 흐르고, 기암변 주위로 수 변풍경을 유람하는 선비들과 전나무, 소나무림, 기암, 다리 등 이 주로 구성된다. 심산의 초입부를 주로 표현하며, 산 아래 수 변공간의 특징을 잘 나타내는 유형이다.

중상류에서 나타나는 수면누정 유형은 산간계류에서 하류로 접어드는 전이공간으로 다양한 점경요소와 정주공간이 부각되 기 시작하는 유형이다. 기암과 함께 조망 공간 및 누정, 민가. 나룻배, 소나무 이외의 버들, 잡수 등이 복합적으로 표현된다. 
Table 9. Main scenery by river area(focus on water image elements and staffage elements)

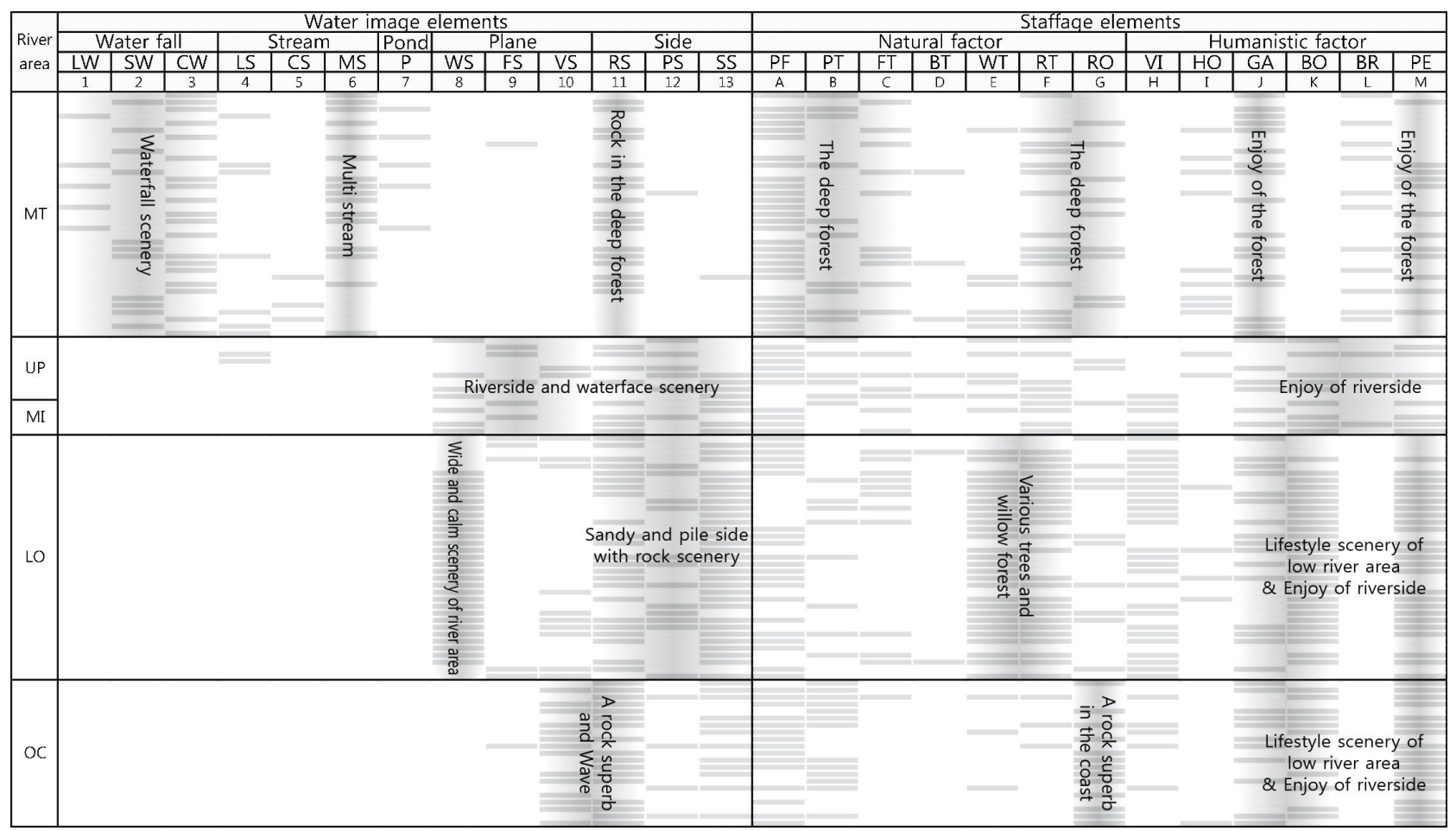

Table 10. Characteristics by river area in the Korean Jingyeong landscape painting

\begin{tabular}{|c|c|c|c|}
\hline \multirow{2}{*}{$\begin{array}{c}\text { Clas- }^{-} \\
\text {sify }\end{array}$} & \multicolumn{2}{|c|}{$\begin{array}{l}\text { Micro-Topography } \\
\text { elements of waterfront }\end{array}$} & \multirow{2}{*}{ Characteristics of scenery } \\
\hline & $\begin{array}{l}\text { Water image } \\
\text { elements }\end{array}$ & $\begin{array}{l}\text { Staffage } \\
\text { elements }\end{array}$ & \\
\hline MT & $\begin{array}{c}\text { Long } \\
\text { waterfall }\end{array}$ & $\begin{array}{l}\text { Deep } \\
\text { forest }\end{array}$ & $\begin{array}{l}\text { Long waterfall scenery in the deep } \\
\text { forest }\end{array}$ \\
\hline MT & $\begin{array}{l}\text { Multi } \\
\text { stream }\end{array}$ & Forest & $\begin{array}{l}\text { Enjoy the multi stream scenery in } \\
\text { the forest }\end{array}$ \\
\hline $\begin{array}{l}\text { UP/ } \\
\text { MI }\end{array}$ & $\begin{array}{l}\text { Water } \\
\text { face }\end{array}$ & Gazebo & $\begin{array}{l}\text { Enjoy the riverside scenery with } \\
\text { gazebo }\end{array}$ \\
\hline LO & Sandy & Gazebo & $\begin{array}{l}\text { Sandy and gazebo scenery of low } \\
\text { river area }\end{array}$ \\
\hline LO & Pile sandy & Ferry & Lifestyle scenery of low river area \\
\hline $\mathrm{OC}$ & Wave & Rock & A rock superb view of the coast \\
\hline
\end{tabular}

수변의 미지형 요소가 풍경의 중심이 되기 시작하는 유형으로 중경(中景)의 산 이미지를 배경으로 산간계류와 하류의 경관 이 교차하는 유형이다.

하류에서 나타나는 토사누정 유형은 겸재 정선의 진경산수 화에서 하류의 풍경을 가장 잘 나타내는 유형이다. 특히 예각 으로 뻗어나가며 중첩된 모래톱의 이미지가 하류의 풍경을 특 징 지어주는 중요 요소로 작용한다. 예각의 토사변과 옹기종기 모여 있는 취락지, 모래톱에 걸쳐진 나룻배, 수변풍경을 조망하 는 정자와 잡수, 송림, 버들이 주로 구성되어 있다.

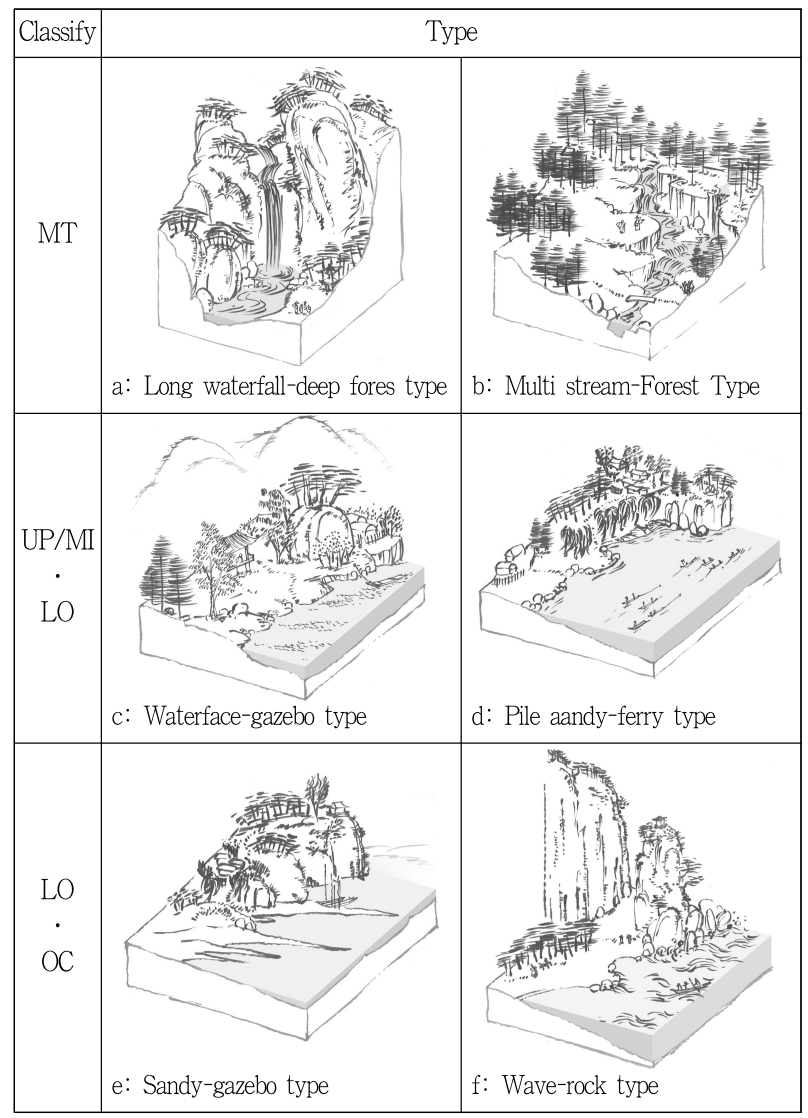

Figure 5. Waterfront landscape style of waterfront in Korean Jingyeong landscape painting 
토파나루 유형은 토사누정 유형과 그 구조가 유사하지만, 인 간 활동이 부각된 생활 풍경이라는 점에서 구분된다. 고깃배와 나룻배들이 취락지와 함께 표현되어 생활과 밀접한 관계를 보 여주는 수변풍경이다. 취락지나 생활공간 주변으로 버들의 선 형군락이 주로 표현되어 하류 특유의 식생 경관을 보여준다.

해(海)에서 나타나는 탄파기암 유형은 해안의 기암절경과 바다 물결의 풍경이 잘 나타나는 유형이다. 바다 물결의 탄파 면은 계곡과 하류구간의 이미지와 구별된다. 파형의 물결과 고 깃배, 송림과 기암변이 기본 배경을 이루며, 정자와 노송이 조 화된 기암괴석이 풍경의 중심을 이룬다. 하류 및 해안으로 내 려올수록 수형상보다는 물 주변의 점경요소가 중요한 경관 요 소로 작용하는 것을 알 수 있다.

\section{VI.결론}

본 연구는 도시공간이나 산간의 풍경과 다른 자연스러운 수 변공간의 미지형 특성을 찾기 위해 겸재 정선의 진경산수화를 분석의 도구로 선정하였다. 「겸재 정선」(Choi, 1993)에서 다루 어진 345 엽 중 수공간이 표현된 105 엽을 하천지리학적 위계에 따라 5 가지로 분류하여 수변 미지형 요소들을 분석하였다. 수 변미지형 요소는 수형상 13 가지, 점경요소 13 가지로 구분하여 분석하였다. 분석한 결과, 수형상과 점경요소가 하천 구역별로 다른 양상으로 표현되었고, 각 구역별 수변 미지형의 특징을 알 수 있었다. 또한 분석된 결과를 바탕으로 진경산수화에서 나타난 대표적인 하경양식과 해안 풍경을 종합하였다.

5 가지 하천 구역별 수변 미지형의 특징은 다음과 같다.

(1) 105 엽의 중 산간계류 35 엽, 상류 9 엽, 중류 5 엽, 하류 35 엽, 바다 21 엽으로 분류되었다. 상류와 중류는 뚜렷한 경계가 불분명하며, 도엽 수가 상대적으로 적게 나타났다. 수형상의 구 분은 산, 상, 중, 하, 해 5 가지 유형에서 뚜렷이 구별된다. 점경 요소는 대부분이 고르게 나타나나 버들, 잡수, 기암, 마을, 배 등의 점경물이 특정 구간에서 집중되어 나타났다.

(2) 산간계류에서 나타는 수변경관은 산경(山景) 표현 중 일 부분으로 작용하여 점경요소들이 수변의 경관을 특정 짓기보 다 수형상과 함께 산수경관을 특징짓는 요소 중 하나로 작용하 는 것으로 볼 수 있다.

(3) 상, 중류 지역은 분류된 도엽 수가 적고, 하천 지형학적 구분의 모호함이 있으나, 산간계류에 비해서 점경요소들이 다 양하게 표현된다. 이는 하류까지 이어져 수변의 다양한 풍경을 만들어내는 요소로 작용하게 된다.

(4) 하류 지역은 화폭의 중심이 수공간과 수변으로 바뀌면 서 수변과 점경요소들이 경관에서 차지하는 비중이 높아진다. 산간계류는 수변의 경관이 산세의 영향을 많이 받는다면 하류 에서는 산세보다 수공간과 수변을 구성하는 요소들의 영향을 많이 받게 된다. 이는 개발이 용이한 하류의 평야지역을 계획
함에 있어 수변의 형태와 점경요소들이 중요함을 시사한다.

(5) 해안 지역은 파형의 물결과 기암괴석의 해안절경이 경 관의 주요 구성요소가 된다. 이는 산간계류와 같이 수공간 자 체의 경관보다는 해안 특유의 지형에 기인하는 경관 구성으로 볼 수 있다.

수변 미지형 경관 특성을 중심으로 분석한 하경양식과 해안 풍경의 특징은 다음과 같다.

산간계류에서는 심산 속 폭포 풍경을 그린 장폭심산형, 수림 지 내 곡류를 유람하는 풍경인 다곡수림형이 대표적인 하경양 식으로 나타났다. 중상류에서는 수변을 유람하거나, 누정이 있 는 풍경인 수면누정형, 하류에서는 하류 특유의 모래톱과 누정 이 있는 풍경인 토사누정형과 하류에서의 인간 활동이 부각된 생활 풍경인 토파나루형이 대표적인 하경양식으로 나타났다. 해안에서는 바닷가의 기암절경이 주 풍경을 이루는 탄파기암 형이 해안 풍경의 특징으로 나타났다.

본 연구에서 진경산수화에 나타난 수변 미지형 경관을 수형 상과 점경요소를 중심으로 분석하였다. 그 결과, 하천 구역별로 미지형 요소가 다르게 나타나는 것을 알 수 있었고, 각 구역별 특징을 설명할 수 있었다. 하지만 본 연구는 진경산수화에서 나타난 수변의 시각적 경관 요소들을 분석하는 것에 그쳤다. 진경산수화의 수변경관에서 볼 수 있는 수변풍경과 인문적인 이용양상의 관계, 하류 경관에서 중요하게 작용하는 토사변의 폭과 구성에 관한 연구 등 후속연구가 필요하다.

주 1. 물의 이미지를 결정하는 다양한 모습. 물의 이미지는 물 자체의 선 형과, 수면의 질감, 그리고 물을 담은 주변의 형태에 따라 다르게 나 타난다.

주 2. 풍경화(風景畫)에 다른 사물(事物)을 그려 넣어서 정취(情趣)를 더 하는 요소. 즉, 산수(山水)에 인물(人物)을, 솔에 돌을 가(加)함과 같 은 부가적인 요소.

주 3. 일정한 시대나 지역의 수변에 나타나 있는 공통된 풍경적 특징. 본 연구에서는 진경산수화의 수변에 나타난 공통된 풍경적 특징을 분 석하였음.

주 4. Choi, W. S.(1993) Korean Jingyeong Landscape Painting. Seoul: Hyeonamsa.

주 5. http://terms.naver.com/list.nhn?cid $=46721 \&$ categoryld $=46882$

주 6. 이후 분석표에서는 표의 구성을 고려하여 5 가지 하천구역에 대해 약 어로 표기하였다. 약어는 Tabel 1 의 괄호에 표기한 단어를 적용하였다.

주 7. 이후 분석표에서는 표의 구성을 고려하여 수형상 및 점경요소 26개 에 대해 약어로 표기하였다. 약어는 Tabel 2, 4 의 괄호에 표기한 단 어를 적용하였다.

주 8. 여울, 모래톱(강가나 바닷가에 있는 넓고 큰 모래벌판), 사주 등에 서 물의 흐름에 의해서 나타나는 물결.

주 9. 흙이 둑의 형태로 쌓인 물의 가장자리.

주 10. 사취(砂觜: 바다 가운데로 길게 뺃어나간 모래톱) 또는 사주(砂洲) 의 발달로 해안의 만(灣)이 바다로부터 떨어져서 생긴 호소(湖沼).

\section{References}

1. Choi, W. S.(1993) Korean Jingyeong Landscape Painting. Seoul: Hyeonamsa. 
2. Kang, M. S.(2001) Pattern classification and characteristics concerning landscape on mountains and hills by using a landscape picture: The case of Seoul city. Journal of the Korean Institute of Landscape Architecture 29(4): 12-23

3. Kim, C. Y.(2005) The Characteristics of Pinus densiflora forest in the "True-view Landscape Paintings" of Late Chosun Dynasty for Forest Landscape construction. Ph.D Thesis, Graduate School, Kookmin University. Korea.

4. Park, C. W., Y. H. Lee and J. J. Kim(2014) The types and characteristics of natural scenery in landscape painting during Joseon
Dynasty. Korean Society of Forest Science 103(4): 687-695.

5. Yoo, K. H. and J. S. Sung(2009) Research on cultural scenic landscape in Jingyeong Sansuhwa: Centering around Gyeomjae Jeongseon's Works. Journal of the Korean Institute of Landscape Architecture 37(1): 87-99.

6. Yoon, M. Y.(2006) A Study on The Texture Stroke of Sansoowha (Paintings of Landscape): Centered on the Real-View Landscape Paintings of Kyem Jae. Master's Thesis, Graduate School, Sungkyunkwan University. Korea.

Received : 28 September, 2018

Revised : 25 November, 2018 (1st)

07 January, 2019

(2nd)

04 February, $2019 \quad$ (3rd)

Accepted : 07 February, 2019

3인익명 심사필 